\title{
Ethnic Innovation and U.S. Multinational Firm Activity
}

\section{Citation}

Foley, C. Fritz, and William R. Kerr. "Ethnic Innovation and U.S. Multinational Firm Activity." Management Science (forthcoming).

\section{Permanent link}

http://nrs.harvard.edu/urn-3:HUL.InstRepos:10018931

\section{Terms of Use}

This article was downloaded from Harvard University's DASH repository, and is made available under the terms and conditions applicable to Open Access Policy Articles, as set forth at http:// nrs.harvard.edu/urn-3:HUL.InstRepos:dash.current.terms-of-use\#OAP

\section{Share Your Story}

The Harvard community has made this article openly available.

Please share how this access benefits you. Submit a story.

\section{Accessibility}




\title{
Ethnic Innovation and U.S. Multinational Firm Activity
}

\author{
C. Fritz Foley and William R. Kerr* \\ Harvard Business School and NBER \\ Boston MA
}

August 2012

\begin{abstract}
This paper studies the impact that ethnic innovators have on the global activities of U.S. firms by analyzing detailed data on patent applications and on the operations of the foreign affiliates of U.S. multinational firms. The results indicate that increases in the share of a firm's innovation performed by inventors of a particular ethnicity are associated with increases in the share of that firm's affiliate activity in countries related to that ethnicity. Ethnic innovators also appear to facilitate the disintegration of innovative activity across borders and to allow U.S. multinationals to form new affiliates abroad without the support of local joint venture partners.
\end{abstract}

JEL Classification: F23, J15, O31, O32, O33.

Key Words: Foreign Direct Investment, Technology Transfer, Patents, Innovation, Research and Development, Ethnic Networks, Diasporas.

\footnotetext{
*Comments are appreciated and can be sent to ffoley@hbs.edu and wkerr@hbs.edu. We are grateful to Olof Åslund, Lee Branstetter, Michael Clemens, Exequiel Hernandez, Sari Kerr, Joan Muysken, Hillel Rapoport, Jasjit Singh, Bill Zeile, and seminar participants at the AFD-World Bank International Migration and Development Conference, American Economic Association, Baruch Business School, Centre for Economic Policy Research Transnationality of Migrants Conference, Census Bureau, Cleveland Federal Reserve Board, Comparative Analysis of Enterprise [Micro] Data Conference, European Regional Science Association, Harvard University, International Workshop on Immigration and Economic Growth, MIT, National Bureau of Economic Research, Sloan Industry Studies, Sweden Conference on Immigration and Labor Market Integration, and University of Connecticut CIBER Conference for insightful comments. This research is supported by the Division of Research of the Harvard Business School. We thank Debbie Strumsky and Bill Lincoln for data assistance. Kerr is a Research Associate of the Bank of Finland and thanks the Bank for hosting him during a portion of this project. An earlier version of this paper was titled, "US Ethnic Scientists and Foreign Direct Investment Placement." The statistical analysis of firm-level data on U.S. multinational enterprises was conducted at the Bureau of Economic Analysis, U.S. Department of Commerce, under arrangements that maintain legal confidentiality arrangements. The views expressed herein are those of the authors and do not reflect the official positions of the U.S. Department of Commerce.
} 


\section{Introduction}

Over the last four decades, science and engineering communities in the United States have become considerably more diverse from an ethnic standpoint. This increased diversity is apparent in the names of inventors listed on U.S. patent applications. Over the 1975-1982 period, 81.3\% of these names were of Anglo-Saxon origin, but by the 2000-2004 period, this share had fallen to $68.0 \%$. Much of this shift, and in fact much of the recent growth in the number of U.S. based scientists and engineers, is a consequence of immigration. In the 2000 Census of Populations, immigrants constituted $25 \%$ and $48 \%$ of the U.S. workforce employed in science and engineering occupations with bachelor's and doctorate educations, respectively.

This paper analyzes the impact ethnic innovators have had on the global operations of U.S. firms by addressing three main questions. First, to what extent do U.S. based innovators of a particular ethnicity facilitate the expansion of U.S. multinationals in countries associated with that ethnicity? Second, how do these ethnic innovators influence the global distribution of the multinational's research and development (R\&D) and patenting activities? Finally, are U.S. multinationals that employ innovators of a particular ethnicity less dependent on joint venture partners when forming new affiliates in countries associated with that ethnicity?

Ethnic innovators are likely to have several attributes that could help U.S. multinationals capitalize on foreign opportunities. Innovators of a certain ethnicity typically have knowledge and experience that are essential for developing products and services targeted at customers in countries associated with that ethnicity. They are likely to have a strong understanding of customer behavior there and to have insights about what types of products would face high levels of demand. Furthermore, ethnic innovators are likely to have language skills and cultural sensitivity that would promote collaboration with innovators and business developers in host countries. Ethnic innovators also have skills that might make them more effective general managers at firms pursuing foreign opportunities, especially those of a technical nature or making use of internationally distributed R\&D efforts. Well-educated individuals of a certain ethnicity typically possess specialized knowledge about how to conduct business in countries associated 
with that ethnicity. Ethnic innovators are also often part of networks that can foster trust and support foreign market access. Such relationships are hard to construct yet crucial in many developed and emerging economies for deal making and business success.

These roles that are potentially played by ethnic innovators appear to be particularly important in the kinds of industries that multinationals compete in. Rauch and Trindade (2002) and others point out the value of ethnic ties in industries producing differentiated products rather than commodities and in industries featuring the use of deep tacit knowledge as opposed to codified information. Saxenian (2006) stresses the importance of ethnic ties for collaboration in industries characterized by fragmented production, modular development, and rapid product cycles. In a report on the Indian Diaspora, the Government of India (2001) notes the role that Indian Americans have played in promoting foreign direct investment by U.S. multinationals in R\&D intensive sectors in particular. Thus, ethnic innovators can reduce the costs of entering foreign locations and facilitate the subsequent growth and success of operations. ${ }^{1}$

In order to study these effects of ethnic innovators, it is particularly useful to work with data that links individuals of particular ethnicities to specific firms. Such data are drawn from a variety of sources. In order to characterize the ethnicity of the science and engineering workforce of firms, the analysis uses a measure based on one type of their output, namely patents. More specifically, the analysis uses detailed filings from the U.S. Patent and Trademark Office for all patents granted from 1975-2008. These filings include the names of the inventors of each patent, their employer, and their location. In order to measure the degree to which innovative activity is performed by individuals from each of nine ethnic groups, procedures that make use of commercial databases of ethnic names assign probable ethnicities to innovators. For example, innovators with the surnames Ming or Yu are assigned a high probability of being of Chinese ethnicity, while innovators with the surnames Agrawal or Banerjee are assigned a high probability of being of Indian ethnicity.

\footnotetext{
${ }^{1}$ Detailed quantification of the mechanisms that give rise to the effects of ethnic ties is sparse. Saxenian et al. (2002) presents the survey based analysis of ethnic scientists and engineers working in Silicon Valley. More than half of the respondents are from large companies.
} 
In order to conduct tests of the relation between ethnic innovation and multinational firm activity, the analysis links data on inventors to data on the activities of U.S. multinational firms captured in the 1982, 1989, 1994, 1999, and 2004 Survey of U.S. Direct Investment Abroad conducted by the Bureau of Economic Analysis (BEA). These data include measures of the activity of each of the foreign subsidiaries of multinationals with a U.S. parent, including measures of assets, sales, employment, and employment compensation. The BEA data also contain information on where multinationals perform R\&D and the ownership structure of foreign affiliates.

Tests that analyze panel data of parent-ethnicity observations reveal that increases in the share of innovation performed by individuals of a certain ethnicity are associated with increases in the share of multinational affiliate activity in countries of that ethnicity. These tests include parent-ethnicity fixed effects so that responses are measured off of time series variation in the role played by innovators of a specific ethnicity at a specific firm, and they include a fixed effect for each ethnicity-year to control for trends in the growth of distinct ethnicities. The results of these tests are particularly pronounced for firms that are likely to place high value on ethnic innovators in the sense that these firms are beginning to perform innovative activity in the countries associated with the ethnicity of the innovators.

The results also do not seem to merely capture the possibility that decisions to employ innovators of a certain ethnicity and to expand in countries associated with that ethnicity are jointly determined. Measures of the share of ethnic innovation reflect shares in the years preceding the measures of affiliate activity. Furthermore, results hold in specifications that use a measure of the predicted extent of ethnic innovation that is computed based on a firm's initial level of ethnic innovation across U.S. cities and the subsequent growth in ethnic innovation by city. This approach is similar to the supply-push immigration framework of Card (2001). Taken together, the results on the relation between the share of innovation performed by an ethnicity and the share of multinational firm activity in countries associated with that ethnicity indicate that ethnic innovators play a significant role in facilitating the expansion of U.S. multinationals in ethnic regions. The knowledge and cultural sensitivities of these innovators thus appear to be 
valuable in helping multinationals unlock key factors to succeeding in these markets.

The data allow for exploration of where U.S. firms conduct R\&D and of the extent to which U.S. firms engage in foreign R\&D that generates patents. Specifications that control for parentethnicity and ethnicity-year fixed effects illustrate that firms with more patents generated by U.S. based innovators of a particular ethnicity conduct more R\&D in the countries associated with that ethnicity. Similar specifications also reveal that firms with more patents generated by U.S. based innovators of a particular ethnicity apply for more patents that list inventors based in countries associated with that ethnicity. These findings also appear to be robust to many concerns about reverse causality. Thus, the paper shows that ethnic innovators facilitate the spread of innovative activity within multinational firms across countries.

Analysis of new affiliates reveals that U.S. multinationals are able to own larger shares of new entities in countries associated with the ethnic heritage of the firms' ethnic innovators. Linear probability specifications that include parent-year fixed effects indicate that higher levels of patenting activity by inventors of a particular ethnicity are associated with higher propensities to form new affiliates as wholly owned or majority owned entities. Similar results are obtained using the approach based on Card (2001). Previous work indicates that one motivation for the use of joint ventures is to gain access to a local partner who can provide information about local demand and customs. ${ }^{2}$ The findings in this paper suggest that U.S. based ethnic innovators possess knowledge and connections that facilitate entry into foreign countries using organizational forms that leave larger ownership stakes in the hands of the multinational.

These findings contribute to several literatures by illustrating the role that firms play in linking ethnic networks, foreign direct investment (FDI), and knowledge diffusion. A significant body of research documents the effects of ethnic connections on certain forms of international economic interaction. Rauch (2001) reviews papers on the economic impact of ethnic networks. Ethnic networks have been shown to play important roles in promoting international trade, investment, and cross-border financing activity, with recent work particularly emphasizing the

\footnotetext{
${ }^{2}$ See, for example, Balakrishnan and Koza (1993) and Desai, Foley, and Hines (2004).
} 
role of educated or skilled immigrants. ${ }^{3}$ Much of this work uses aggregated data and crosssectional techniques, so the panel analysis of firm-level data in this paper complements this literature and identifies key mechanisms in these linkages.

Recent work also considers how social and ethnic ties facilitate transfers of technology. ${ }^{4}$ Individuals who are geographically mobile appear to play a significant role in these kinds of transfers. ${ }^{5}$ Because this paper's findings illustrate a mechanism by which knowledge is transferred globally, it also adds to research on the role multinational firms play in the international diffusion of knowledge. ${ }^{6}$ Finally, the results inform a growing body of work that analyzes firm decisions about whether to locate innovative activity in a single place or in multiple locations. ${ }^{7}$

The remainder of this paper is organized as follows. Section 2 provides details about the data. Section 3 includes three parts; the first describes the analysis of how U.S. based ethnic innovation shapes the share of a multinational's activity in countries associated with that ethnicity. The second part describes the analysis of the extent to which ethnic innovators facilitate the disintegration of innovative activity across borders. The third part presents the examination of whether firms that employ innovators of a certain ethnicity are less likely to use joint ventures when they form new affiliates in countries associated with that ethnicity. Section 4 concludes.

\section{Data}

This section first describes the ethnic patenting data developed for U.S. multinational firms. The second part describes the BEA data on the foreign operations of these firms and the merger of the two data sources.

\footnotetext{
${ }^{3}$ Papers in this literature include Saxenian (1999, 2002, 2006), Arora and Gambardella (2005), Buch, Kleinert, and Toubal (2006), Kugler and Rapoport (2007, 2011), Bhattacharya and Groznik (2008), Docquier and Lodigiani (2010), Iriyama, Li, and Madhavan (2010), Huang, Jin, and Qian (2011), Nachum (2011), Hernandez (2011), Javorcik et al. (2011), and Rangan and Drummond (2011). Related work on trade includes Gould (1994), Head and Ries (1998), Rauch (1999), Rauch and Trindade (2002), Kerr (2009), Rangan and Sengul (2009), and Hatzigeorgiou and Lodefalk (2011). Clemens (2009) and Docquier and Rapoport (2011) provide broader reviews.

${ }^{4}$ Examples of this work include Agrawal, Cockburn, and McHale (2006), MacGarvie (2006), Oettl and Agrawal (2008), Kerr (2008), Papageorgiou and Spilimbergo (2008), and Agrawal et al. (2011).

${ }^{5}$ For evidence of this point, see Almeida and Kogut (1999), Rosenkopf and Almeida (2003), Nanda and Khanna (2010), Choudhury (2010), and Hovhannisyan and Keller (2010).

${ }^{6}$ Papers on this topic include Keller (2004), Veugelers and Cassiman (2004), Singh (2004, 2005, 2007), MacGarvie (2005), Branstetter (2006), Alcacer and Chung (2007), and Nachum, Zaheer, and Gross (2008).

${ }^{7}$ Work on this topic includes Zhao (2006), Singh (2008), Alcacer and Zhao (2011), and Zhao and Islam (2011).
} 


\subsection{Data on Ethnic Innovators}

Measures of the ethnicity of innovators employed at U.S. multinational firms are created on the basis of data on each patent granted by the United States Patent and Trademark Office between January 1975 and May 2008. Hall, Jaffe, and Trajtenberg (2001) provide extensive details about these data, and Griliches (1990) surveys the use of patents as economic indicators of technological advancement. Each patent lists at least one and often several inventors and includes information on the location and employer of each inventor. These data are extensive, containing over eight million inventors and four million granted patents during the sample period. Much of the analysis below considers the impact of U.S. based innovators, and inventors are classified as being based in the U.S. if they are located in a U.S. city. Although the data are selected using a screen related to the date of patent grants, the date of patent applications is used to identify the timing of innovative activity.

The ethnicity of inventors is not listed on patents, but it is possible to determine their probable ethnicity through their names. The matching approach exploits the fact that people with particular first names and surnames are likely to be of a certain ethnicity and makes use of two databases of ethnic names. The first was developed by the Melissa Data Corporation for use in direct-mail advertisements and the second by LSDI, also for marketing purposes. The process affords the distinction of nine ethnicities: Anglo-Saxon, Chinese, European, Hispanic, Indian, Japanese, Korean, Russian, and Vietnamese. When there is more than one inventor associated with a patent, each individual is given an ethnicity assignment and then these are averaged. The name match rate is $99 \%$. Kerr $(2007,2010)$ provides details on the matching process, lists frequent ethnic names, and provides descriptive statistics and quality assurance exercises.

Table 1 displays the share of U.S. based innovation performed by ethnic innovators working at public companies over the time periods that are analyzed in more detail in Section 3. As mentioned in the introduction, the Anglo-Saxon ethnic share declines from $81.3 \%$ of U.S. domestic patents for public firms in the $1975-1982$ period to $68.0 \%$ in the $2000-2004$ period. This declining

share is primarily due to the growth in innovation among Chinese and Indian ethnicities, which 
increase from under $3 \%$ to $9.5 \%$ and $7.3 \%$, respectively. Ethnic inventors are more concentrated in high-tech industries than in other industries, and this gap has widened substantially over the past three decades. Furthermore, while ethnic innovation was particularly prevalent in pharmaceuticals and chemicals industries in the 1970s, ethnic contributions to innovation in computers and electronics industries were particularly prevalent in the 2000s.

The tests below exploit variation within firms in the share of innovation performed by inventors of a certain ethnicity and control for ethnicity-year fixed effects. Therefore, the tests depend on there being variation in the evolution of ethnic innovation across firms. Figure 1, which is constructed from the patent database, illustrates that such heterogeneity exists among seven large U.S. firms that report earning foreign income in Compustat. ${ }^{8}$ Each line plots the share of U.S. based innovation that is attributed to Chinese and Indian innovators at one of seven large firms. As indicated, there is substantial variation in the levels and changes of the share of innovation performed by Chinese and Indian inventors across firms.

The analysis described below uses data on ethnic innovation aggregated to the firm-ethnicityyear level. The analysis calls for measures of ethnic innovation that precede the measures of the outcomes of interest. Therefore, levels and shares of innovation performed by each ethnicity for each firm are calculated for each time period listed in Table 1. The years associated with each period relate to the timing of patent applications. On average, slightly more than 50 patents per firm and time period are used to calculate these relative ethnic contributions.

\subsection{Data on U.S. Multinational Firm Activity}

Data on the activities of U.S. multinational firms are drawn from the Survey of U.S. Direct Investment Abroad conducted by the Bureau of Economic Analysis. U.S. direct investment abroad is defined as the direct or indirect ownership or control by a single U.S. legal entity of at least $10 \%$ of the voting securities of an incorporated foreign business enterprise or the equivalent interest in an unincorporated foreign business enterprise. A U.S. multinational firm includes the

\footnotetext{
${ }^{8}$ In order to protect the confidentiality of the BEA data, to which the patent data are linked, the names of these firms are not identified.
} 
U.S. legal entity that has made the direct investment, called the U.S. parent, and at least one foreign business enterprise, called a foreign affiliate. ${ }^{9}$ The sample includes records drawn from the 1982, 1989, 1994, 1999, and 2004 benchmark surveys. These surveys capture financial and operating data for each foreign affiliate of each U.S. multinational, so it is possible to create a panel of data on the assets, sales, employment, and employment compensation for each firm in each country. The BEA data also include information on the parent's ownership share of each affiliate, as well as the amount affiliates spend on R\&D.

A number of steps were taken to link the data on U.S. multinationals with the data on ethnic innovators. Data on the Committee on Uniform Security Identification Procedures codes (CUSIPs) of employers of ethnic innovators were taken from the NBER Patent Citations Data File and have been manually updated to assign patents to subsidiaries of major corporations and to account for major mergers and acquisitions. ${ }^{10}$ These CUSIPs were matched with Employment Identification Numbers (EINs) from Compustat. The BEA data include EINs, and an automated merge was performed on the basis of these. Automated matches were manually confirmed and augmented with a visual comparison of firm names. One notable consequence of this process is that the matched sample only includes publicly listed firms because CUSIPs are used as the starting point.

Much of the analysis below also aggregates the data on U.S. multinational firm activity to the firm-ethnicity-year level. This requires relating ethnicities to countries. There is a one-to-one mapping of ethnicity and country for five cases. Chinese, European, and Hispanic ethnicities each relate to more than one country. Chinese economies include Mainland China, Hong Kong, Macao, Singapore, and Taiwan. European economies include Austria, Belgium, Denmark, Finland, France, Germany, Italy, Luxembourg, Netherlands, Norway, Poland, Sweden, and Switzerland. Hispanic economies include Argentina, Belize, Brazil, Chile, Colombia, Costa Rica, Dominican Republic, Ecuador, El Salvador, Guatemala, Honduras, Mexico, Nicaragua, Panama, Paraguay,

\footnotetext{
${ }^{9}$ As a result of confidentiality assurances and penalties for noncompliance, BEA believes that survey coverage is close to complete and levels of accuracy are high. Mataloni (1995) and Mataloni and Yorgason (2002) provide further details on these FDI data.

${ }^{10}$ Debbie Strumsky and Bill Lincoln performed portions of this update.
} 
Peru, Philippines, Portugal, Spain, Uruguay, and Venezuela.

The final sample has several limitations, but it offers broad coverage of U.S. multinational activity nonetheless. The firms only include publicly listed entities that have been granted patents during the sample period and have a foreign affiliate. Anglo-Saxon innovators and multinational activity in Anglo-Saxon countries are removed from the sample because such innovators are less likely to be recent immigrants and to have distinctive ties to countries associated with their ethnicity. Although it is not possible to identify ethnic names associated with many countries like Thailand or Saudi Arabia, the aggregated data cover 45 foreign countries. The final sample includes 641 firms which account for more than two-thirds of aggregate foreign affiliate sales in each of the locations associated with non-Anglo-Saxon ethnicities in each benchmark year. Furthermore, these shares are higher in industries that intensively employ patenting. Table 2 presents descriptive statistics for the variables used in the analysis below.

\section{Empirical Tests and Results}

This section describes the empirical tests and presents the results. It contains three subsections. The first presents analyses of the relation between the share of innovation performed by a particular ethnicity and the share of multinational affiliate activity that occurs in countries associated with that ethnicity. The second, which includes two parts, explores the association between ethnic innovation and the amount and location of innovative activity that U.S. multinationals perform outside of the U.S. The third describes tests of whether U.S. multinationals own larger shares of affiliates in countries that are of similar ethnicity to the firms' innovators.

\subsection{Ethnic Innovation and Shares of Multinational Affiliate Activity}

One of the questions this paper seeks to address is whether U.S. based innovators of a particular ethnicity bolster the expansion of U.S. multinational firms in countries associated with that ethnicity. Several tests shed light on this question by examining the relationship between the

share of innovation performed in the U.S. by a certain ethnicity and the subsequent share of affiliate activity that occurs in the countries associated with the ethnicity of those inventors. 
The basic estimating equation takes the following form:

$$
M N E \%_{f e t}=\phi_{f e}+\eta_{e t}+\beta \cdot E I \%_{f e t}+\epsilon_{f e t} .
$$

The observations employed in this test relate to a particular firm for a particular ethnicity in a particular year. $M N E \%_{\text {fet }}$ is a measure of the share of firm $f$ 's foreign activity that occurs in countries associated with ethnicity $e$ in benchmark survey year $t$. Four measures of this share are calculated using data on foreign affiliate assets, sales, employment, and employment compensation. EI\% fet measures the share of U.S. based innovation performed by individuals of ethnicity $e$ in the period leading up to benchmark survey year $t$. These periods span seven years for the 1982 and 1989 benchmark years and five years for the 1994, 1999, and 2004 benchmark years. $\phi_{f e}$ and $\eta_{e t}$ are vectors of firm-ethnicity and ethnicity-year fixed effects. Standard errors are clustered by ethnicity-year.

Several features of this specification are noteworthy. The firm-ethnicity fixed effects remove time invariant differences in the extent to which firms invest in countries associated with a particular ethnicity and employ innovators of a particular ethnicity. The $\beta$ parameter is therefore identified off of changes in these firm characteristics over the sample period. A potential concern is that there appear to be secular trends in the shares of innovation performed by certain ethnicities, as indicated in Table 1, and these might coincide with secular trends in the growth of affiliate activity. Including ethnicity-year fixed effects addresses this concern. Finally, firmspecific changes in the scale of activity could generate coincident changes in the levels of ethnic innovation and multinational affiliate activity. Measuring ethnic innovation and the location of multinational affiliate activity using shares, as opposed to levels, addresses this concern.

Table 3 presents results of tests using specification (1). The dependent variable in the first column is the share of affiliate assets in countries associated with a particular ethnicity. The 0.1008 coefficient in column 1 is statistically significant and implies that a 10 percentage point increase in the share of innovation by individuals of a particular ethnicity is associated with a 1.0 percentage point increase in the share of multinational affiliate activity in countries related to that ethnicity. Consistent results are obtained for other measures of the distribution of affiliate 
activity that are computed using data on sales, employment, and employment compensation, as indicated in columns 2-4. Because the estimates that appear in columns 3 and 4 are of a similar magnitude, the results suggest that changes in the share of ethnic innovation are not associated with changes in the wage structures of foreign operations.

These basic results are robust to a variety of checks. They do not depend on the inclusion of any particular ethnicity; the results hold dropping each of the ethnicities. They also do not appear to be a consequence of activity in particular industries where patenting is especially prevalent. Removing firms that are primarily engaged in the production of pharmaceuticals or other chemicals; audio, video and communication equipment; or computer and office equipment does not overturn the results. The measured relationships also do not seem to be driven by the recent rapid growth in innovative activity by individuals of Chinese or Indian ethnicity; removing observations related to the 2004 benchmark survey does not affect the results.

The findings in Table 3 suggest that innovation by individuals of a particular ethnicity facilitates the expansion of U.S. multinationals in countries associated with that ethnicity. If this interpretation is correct, one would expect U.S. based ethnic innovation to have particularly large effects when firms are beginning to engage in innovative activity in countries associated with an ethnicity. U.S. based ethnic innovators could play a valuable role in promoting cooperation between innovators working in different locations and in identifying products and services that could be further developed abroad to meet local demands. In order to identify such situations, it is possible to use the patent data described above to isolate firm-ethnicities for which the firms had: 1) previously applied for patents for innovations of U.S. based inventors and 2) subsequently applied for patents for innovations involving inventors located in countries of a particular ethnicity. This sample is labeled the sample of new foreign innovators.

Table 4 presents the results of running specification (1) on two subsamples, the sample of new foreign innovators and other observations. The top panel presents results for the new foreign innovator sample, and the bottom panel presents results for other observations. The 0.2155 coefficient on the Ethnic Share of U.S. Patents in the top panel is statistically significant and 
much larger than the 0.0551 insignificant coefficient on this variable in the bottom panel. The larger coefficient implies that, in this subsample, a 10 percentage point increase in the share of innovation by individuals of a particular ethnicity is associated with a 2.2 percentage point increase in the share of multinational affiliate activity in countries related to that ethnicity. A similar pattern holds across the panels for the specifications in columns 2-4. The results therefore indicate that the association between U.S. based ethnic innovation and multinational affiliate activity is more pronounced in situations where U.S. based ethnic innovations are arguably more valuable to the firms they work for.

An additional concern that can be raised about Table 3's results is that they may reflect omitted variable bias or reverse causality. In particular, firms might jointly make decisions about the use of ethnic innovators and about where to expand internationally. Alternatively, conducting FDI abroad may lead to identification of promising scientists and engineers that are then brought to the U.S. to work. It is therefore desirable to create an alternative measure of ethnic innovation that is more likely to exhibit exogenous variation.

One such measure can be computed using the patent data and is based on the initial distribution of ethnic innovation across U.S. cities for specific firms and the subsequent local growth of ethnic innovation. This framework is based on the supply-push work of Card (2001), which has also been applied by Hunt and Gauthier-Loiselle (2010) and Kerr and Lincoln (2010) in a science and engineering context. The identification builds off the fact that growth in the U.S. based science and engineering workforce has differed across ethnicities, in part because of differences in immigration patterns. For example, many Chinese innovators settle in San Francisco, while many Hispanic innovators settle in Miami. The growth of Chinese scientists and engineers in the U.S. is therefore more likely to influence firms in San Francisco than firms in Miami.

More specifically, the Predicted Ethnic Share of U.S. Patents is computed by first calculating

$$
E x p E I_{f e t}=\sum_{c} E I_{f, c e t_{0}}\left(\frac{E I_{-f, c e t_{0}}}{E I_{\text {cet }_{0}}} \cdot \frac{E I_{-f, c e t}}{E I_{-f, c e t_{0}}}+\frac{E I_{f, c e t_{0}}}{E I_{\text {cet }}} \cdot \frac{E I_{-f, e t}}{E I_{-f, e t_{0}}}\right) .
$$

The first term in the expression following the summation captures the initial distribution of ethnic innovation for a firm. It is the count of patents applied for by firm $f$ in which the 
inventor is based in city $c$ and is of ethnicity $e$ at time $t_{0}$, which is the first benchmark year the firm appears in the data. The analysis considers 281 cities defined as Metropolitan Statistical Areas, and Kerr (2010) lists major cities and their inventor shares.

The terms within the parentheses measure growth in patenting activity for firms other than firm $f$. Taking this approach increases the likelihood that this measure of ethnic innovation is exogenous. For cities in which a single firm is responsible for a large share of patenting activity, growth in local patenting by ethnicity for other firms can exhibit irregular properties. Therefore, the terms in parentheses calculate growth rates using a weighted average of cityspecific and national growth in ethnic patenting for other firms. The two weights are captured by $\frac{E I_{-f, c e t}}{E I_{\text {cet }}}$ and $\frac{E I_{f, c e t_{0}}}{E I_{\text {cet }}}$. These two weights sum to one, and the first is the share of the initial patent counts attributable to firms other than firm $f$, while the second is the share attributable to firm $f . \frac{E I_{-f, c e t}}{E I_{-f, c e t}}$ is the local growth in patent applications filed by firms other than firm $f$ for patents in which the inventor is based in city $c$ and is of ethnicity $e$ in period $t$ relative to $t_{0}$. $\frac{E I_{-f, e t}}{E I_{-f, e t_{0}}}$ is a similar measure of growth, but it is measured across all cities and is not city specific. As such, city-specific growth gets more weight when a firm is responsible for a smaller share of total innovative activity in the city.

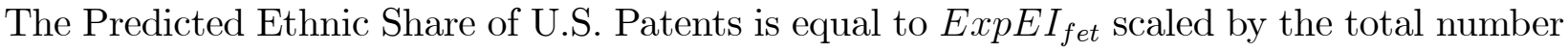
of patents that firm $f$ is expected to apply for in year $t$, and it is thus a predicted share for each ethnicity in each period. The predicted share for an individual ethnicity in firm $f$ increases over the sample period if the initially observed ethnic innovation of the firm occurred in cities that subsequently experienced strong inflows of researchers of that ethnicity. The spatial distribution of each firm is held fixed at its initial level to avoid capturing firms expanding into new cities to take advantage of differential growth in innovation.

Table 5 presents the results of tests that make use of this alternative measure of ethnic innovation. As in the previous two tables, the specifications presented include firm-ethnicity and ethnicity-year fixed effects, and standard errors are clustered by ethnicity-year. It is noteworthy that the fixed effects absorb the impact of differences in the initial distribution of ethnic innova- 
tion for a firm as well as the aggregate growth trends of different ethnicities. The identification therefore comes from differences in the extent to which firms were exposed to different growth in ethnic innovation across U.S. cities. The specification in the first column provides evidence that the Predicted Ethnic Share of U.S. Patents is positively correlated with the Ethnic Share of U.S. Patents. The 0.1926 coefficient on the Predicted Ethnic Share of U.S. Patents indicates that the two measures are closely related, but it is less than one, implying that factors besides growth in ethnic innovation across cities influence how inventor compositions evolve in large firms.

The dependent variables in the next four columns are the same ones considered in Table 3. The coefficients on Predicted Ethnic Share of U.S. Patents are positive in each of these specifications, and in three of the four specifications they have a similar or larger magnitude than the coefficients on the Ethnic Share of U.S. Patents reported in Table 3. The coefficients are statistically significant in columns 3 and 4 . The findings indicate that changes in ethnic innovation related to plausibly exogenous changes in the growth of ethnic innovation across U.S. cities are associated with changes in the distribution of U.S. multinational affiliate sales and employment. Therefore, these results alleviate some concerns about the potential endogeneity of the Ethnic Share of U.S. Patents in Table 3. The tests are not perfect, as a forward-looking manager might have located the firm's initial inventive facilities to attract innovators of a particular ethnicity in anticipation of foreign expansion, for example. Nevertheless, this approach does show the robustness of Table 3's results to several endogeneity concerns. ${ }^{11}$

\subsection{Ethnic Innovation and the Disintegration of Innovative Activity}

Two pieces of analysis shed light on the role of ethnic innovators in breaking up innovative activities across borders. The first piece examines affiliate R\&D activity, and the second piece considers the patenting of foreign innovations.

\footnotetext{
${ }^{11}$ It is possible to repeat the analysis that appears in Table 4 using the predicted ethnic share of U.S. patents as the measure of ethnic innovation. Unreported results show that, as in the version of Table 4 that appears in the paper, the coefficients in the top panel are larger than those in the bottom panel, typically by a factor of more than 2. The coefficient on Predicted Ethnic Share of U.S. Patents is statistically significant at the $5 \%$ level in the specification that explains the Share of Sales and uses the New Foreign Innovators subsample.
} 


\subsubsection{Affiliate R\&D Activity}

Although U.S. multinationals perform a large share of their R\&D within the U.S., this share has been shrinking. According to the aggregate published BEA data, majority owned foreign affiliates performed $6.4 \%$ of U.S. multinational R\&D in 1982, but this ratio increased to $13.6 \%$ in 2004. This globalization of R\&D activities has received considerable recent attention in the academic literature. ${ }^{12}$ While early foreign $R \& D$ efforts focused on refining products so they were suitable for foreign markets and on accessing foreign technologies, recent efforts also attempt to tap into the large supply of foreign scientists and engineers regardless of their knowledge of specific foreign technologies. ${ }^{13}$ U.S. based ethnic innovators could be especially valuable in facilitating the spread of inventive activity within firms across countries.

Specifications that take the following form shed light on this possibility:

$$
\text { ForeignR\&D } D_{f e t}=\phi_{f e}+\eta_{e t}+\beta \cdot \ln \left(E I_{f e t}\right)+\epsilon_{f e t} .
$$

ForeignR\& $D_{f e t}$ is a measure of the $\mathrm{R} \& \mathrm{D}$ conducted by firm $f$ in countries associated with ethnicity $e$ in benchmark year $t$. Like specification (1), this specification includes firm-ethnicity and ethnicity-year fixed effects. Because the dependent variable does not measure the share of $R \& D$ performed in countries of a particular ethnicity but instead captures the level of $R \& D$ activity, the measure of ethnic innovation is not measured as a share either. $\ln \left(E I_{\text {fet }}\right)$ is a measure of the number of patents a firm applies for in the period before the benchmark year for which the inventor is based in the U.S. and is of ethnicity $e$. One concern that could be raised about this approach is that $\ln \left(E I_{f e t}\right)$ might reflect something about the overall scale of parent activity. Growing firms might increase employment of ethnic innovators and be more likely to conduct R\&D abroad. To address this possibility, tests include the log of one plus parent $\mathrm{R} \& \mathrm{D}$ expenditures and the log of one plus parent sales.

Table 6 presents the results. The dependent variable used in the first four specifications is a dummy equal to one for firms that conduct $\mathrm{R} \& \mathrm{D}$ in countries associated with a particular

\footnotetext{
${ }^{12}$ See, for example, Dalton et al. (1999), Freeman (2006), Zhao (2006), and Puga and Trefler (2010).

${ }^{13}$ Studies of these issues include Niosi (1999), von Zedtwitz and Gassmann (2002), Thursby and Thursby (2006), and National Science Foundation (2010).
} 
ethnicity, and the dependent variable in the last four specifications is the log of one plus the value of those $R \& D$ expenditures. The coefficients on the log of ethnic patenting are positive and significant in the first two specifications, the second of which includes controls for the scale of parent activity. The 0.0396 coefficient in column 2 implies that a one standard deviation increase in the log of ethnic U.S. patents is associated with a 4.1 percentage point increase in the likelihood of conducting $\mathrm{R} \& \mathrm{D}$ in countries associated with that ethnicity. This effect is sizeable given that the mean likelihood that a firm conducts R\&D in countries associated with a particular ethnicity is $38.4 \%$, implying a relative increase of $10.6 \%$. The specifications in columns 5 and 6 repeat this analysis using the log of one plus foreign affiliate R\&D expenditures, and the coefficients on the log of ethnic patenting variable are again positive and significant. ${ }^{14}$

As with the tests presented in Table 3, the tests in columns 1, 2, 5, and 6 of Table 6 are subject to concerns about omitted variable bias and reverse causality. It is possible to address these concerns, in part, using the approach based on Card (2001) that is described above. The variable Log $\left(1+\right.$ Predicted Ethnic U.S. Patents) is calculated by computing ExpE $I_{f e t}$ and then taking the log of one plus this value. This alternative measure of ethnic patenting is used in columns $3,4,7$, and 8 of Table 6 . It has a positive coefficient in all four of these specifications, but the coefficients are only statistically significant in the last two. These findings provide some evidence that the results are not driven by omitted variable bias or reverse causation. ${ }^{15}$

Thus, the results in Table 6 indicate that U.S. based innovation by inventors of a certain ethnicity facilitates R\&D activity in countries associated with that ethnicity. Further evidence of the manner in which ethnic innovators support the disintegration of inventive activity across borders comes from the analysis of patent data.

\footnotetext{
${ }^{14}$ These results, along with those reported in Tables 7 and 8 that are discussed below, are robust to measuring ethnic patenting as simply the log of the number of patents filed by inventors of a particular ethnicity or the number of such patents winsorized at the $1 \%$ level in each tail.

${ }^{15}$ Some limitations of these tests are worth noting. The same concerns about forward-looking managers described in the context of Table 5 appear here as well. In addition, if firms locate operations in certain U.S. cities and certain foreign countries that experience correlated rates of growth, the findings might reflect this correlation rather than a relationship between ethnic U.S. patenting and foreign R\&D activity.
} 


\subsubsection{Patenting Foreign Inventions}

If U.S. based ethnic innovators promote meaningful foreign R\&D, this activity should result in patents that list inventors located outside of the U.S. This specification tests this idea:

$$
\text { ForeignPatent }_{\text {fet }}=\phi_{f e}+\eta_{\text {et }}+\beta \cdot \ln \left(E I_{f e t}\right)+\epsilon_{f e t} .
$$

ForeignPatent $_{\text {fet }}$ is a measure of the extent to which firm $f$ applies for at least one patent in which at least one inventor is based in a country associated with ethnicity $e$ in the period that precedes benchmark year $t .{ }^{16}$ Other variables are defined as in specification (3). The sample employed in this test differs from the samples used elsewhere because the BEA data are not required in order to conduct it; therefore, the samples used here are somewhat larger. This sample includes multinationals that report foreign pretax income in Compustat, and it is not restricted to firm-ethnicity observations where a foreign affiliate exists in the BEA data.

Table 7 shows the results of analysis that explains foreign patenting using specifications like the ones presented in Table 6. The coefficients on the log of ethnic patenting are positive and significant in columns $1,2,5$, and 6 , indicating that an increase in innovation by U.S. based inventors of a certain ethnicity is correlated with changes in the extent of innovative activity that takes place in countries associated with that ethnicity. The coefficients on the measure of ethnic patenting generated using the approach based on Card (2001) are also positive and significant, suggesting that the foreign patenting outcomes are robust to many endogeneity concerns. These results are consistent with the previous findings on affiliate R\&D activity. They suggest that U.S. based ethnic inventors promote innovation activity abroad.

\subsection{Ethnic Innovations and Affiliate Ownership Structure}

If innovators of a certain ethnicity facilitate the expansion of U.S. multinationals and innovative activity in countries associated with that ethnicity, they might also be associated with distinct ownership choices for new affiliates in those countries. Prior work on ownership structure points

\footnotetext{
${ }^{16}$ One concern that could be raised about this analysis is that firms are not required to patent foreign innovations in the U.S. The inclusion of parent firm-ethnicity and ethnicity-year fixed effects alleviates this concern as the fixed effects control for any systematic differences in patenting propensities on either of these dimensions.
} 
out that local partners can play a valuable role in supporting the activities of U.S. multinationals abroad. Local partners often have valuable market information and local connections that can help generate business. These benefits of shared ownership are weighed against higher coordination costs and considerations related to ceding control when multinational firms make ownership choices. Local partners typically hold larger ownership stakes when they bring more value by playing a leadership role. However, a multinational that employs ethnic innovators might have more confidence operating in host countries and might therefore cede less power to such partners. Ethnic innovators can often provide both knowledge and connections that facilitate foreign activity. These advantages are often cited as a key advantage that diasporas confer. Therefore, ethnic innovators could enable U.S. multinationals to hold more control rights in foreign affiliates by maintaining whole or majority ownership.

Specifications that consider this possibility take the following form:

$$
O W N_{\text {ayet }}=\eta_{f t}+\beta \cdot \ln \left(E I_{\text {fet }}\right)+\epsilon_{\text {aet }} .
$$

The dependent variable measures the extent to which the parent owns the equity of affiliate $a$ located in country $y$ associated with ethnicity $e$ at time $t$. The analysis considers two measures of ownership: a whole ownership dummy which is equal to one for affiliates that are wholly owned by their parent, and a majority ownership dummy which is equal to one for affiliates that are at least $50 \%$ owned by their parent. To isolate new affiliates, the sample only includes affiliates the first time they appear in the BEA benchmark surveys, and affiliates that appeared in the first survey in the sample, which occurred in 1982, are excluded. $80 \%$ of new affiliates are wholly owned by their parents, and $92 \%$ of new affiliates are majority owned. $\ln \left(E I_{f e t}\right)$ is the log of the count of the number of patents the firm applies for in the period before benchmark year $t$ for which the inventor is based in the U.S. and is of ethnicity $e$.

The specifications also include some controls. Several countries limit the ownership stake that can be held by U.S. multinationals during the sample period. Specifications include a measure of these restrictions to capture their impact and to compare the relationship between restrictions and ownership choices with the relationship between ethnic innovation and ownership choices. 
The Ownership Restriction Dummy is a dummy based on Shatz (2000), and it is equal to one if both the acquisition and sectoral score are at least three in a particular country and year. Prior work, including Desai, Foley, and Hines (2004), illustrates that affiliates that engage in more trade with their parents are less likely to be minority owned. Specifications include the ratio of affiliate imports from their parents to affiliate sales and the ratio of affiliate exports to their parents to affiliate sales as controls for this effect. The specification also includes parentyear fixed effects $\eta_{f t} \cdot{ }^{17}$ The specifications are linear probability models, and standard errors are clustered by parent-year. The sample used in this analysis differs from that used in the analysis in Tables 3-6 because each observation corresponds to a new affiliate, rather than to a firm's activity in countries associated with a particular ethnicity.

The results of the specifications appear in Table 8. The positive and significant coefficient in the first column implies that firms that have more innovation performed in the U.S. by inventors of a certain ethnicity are more likely to wholly, as opposed to partially, own new affiliates in countries associated with that ethnicity. The specification in the second column contains the controls, including the ownership restriction dummy, which has a negative coefficient, indicating that ownership restrictions limit the use of whole ownership, as one might expect. The results in column 2 imply that a one standard deviation decrease in ethnic innovation is associated with a decrease in the use of whole ownership that is about two-thirds the size of the decrease associated with ownership restrictions. Consistent with prior work, the coefficients on the measures of related party trade are positive and significant. This kind of trade appears to be easier to manage between entities that are under common control. It is noteworthy that the specifications do not control for affiliate R\&D activity. As a consequence, it is difficult to rule out the possibility that the relationship between the activities of ethnic innovators and ownership choice reflects concerns about the protection of intellectual property. ${ }^{18}$

\footnotetext{
${ }^{17}$ Previous specifications include parent-ethnicity and ethnicity-year fixed effects. There is not sufficient entry within parent-ethnicities to identify effects when parent-ethnicity fixed effects are included. If ethnicity-year fixed effects are included, there is little variation in ownership restriction within ethnicity-years, yielding results that do not allow for a comparison of the relationship between ownership restrictions and ownership structure and the relationship between ethnic innovation and ownership structure.

${ }^{18}$ The Survey of U.S. Direct Investment Abroad does not collect R\&D expenditure data from minority owned affiliates, so it is not possible to include an affiliate measure of R\&D expenditures in the tests. Furthermore, the
} 
Columns 3 and 4 present tests using the measure of ethnic patenting that is generated using the approach based on Card (2001), and the results are robust in these tests. The next four columns present a similar analysis where the dependent variable is a dummy for the use of majority ownership. The results are similar. Thus, ethnic innovators appear to allow U.S. multinationals to serve countries without the assistance of a local partner. Using ethnic innovators therefore likely increases the ability of multinationals to enjoy the coordination benefits that come with majority and whole ownership. These results support the view that high-skilled ethnic employees possess knowledge and connections that aid firms in navigating entry abroad.

\section{Conclusion}

This paper studies the effects that ethnic scientists and engineers have on the global activities of the firms that employ them. The analysis uses detailed data on the names of inventors that appear in patent applications to infer the ethnicity of U.S. based innovators. This information is used in conjunction with detailed data on affiliates of U.S. multinationals.

Tests reveal that increases in the share of innovation performed by inventors of a certain ethnicity are associated with increases in the share of affiliate activity in countries related to that ethnicity. This result is stronger for firms that are more likely to value ethnic innovators; more specifically, it is stronger when firms are beginning to engage in innovative activity abroad, and ethnic innovators could play a role in facilitating cooperation between innovators working in different locations and in identifying products and services that could be developed further to meet foreign demands. This result also holds in tests that use a measure of ethnic innovation that exhibits plausibly exogenous variation. This result implies that innovators of a particular ethnicity facilitate the expansion of U.S. multinational firms in countries associated with that ethnicity, raising the conjecture that ethnic innovators enhance the competitiveness of U.S. firms in ethnic regions.

sample used in this analysis only includes new affiliates, and affiliates tend to conduct little or no R\&D when they are first established. However, it is possible to include an industry measure of R\&D expenditures in these tests. Doing so does not materially change the results. 
The data also illustrate that firms with more innovative activity performed by U.S. based inventors of a certain ethnicity are more likely to conduct $\mathrm{R} \& \mathrm{D}$ and to generate patents in countries associated with that ethnicity. Recent literature points out that firms are increasingly breaking up innovative activities across countries to perform different steps in settings where they can be performed most efficiently. The findings in this paper suggest that ethnic innovators facilitate this change in the manner in which innovation occurs.

Finally, tests show that U.S. multinational firms rely less on joint venture partners when forming new affiliates in countries that are home to the firms' ethnic innovators. Joint ventures typically entail substantial coordination costs and are subject to conflicts over transfer pricing issues and technology transfers. Ethnic innovators appear to provide insights about foreign markets that allow multinationals to majority or wholly own foreign affiliates.

\section{References}

Agrawal, Ajay, Iain Cockburn, and John McHale, "Gone But Not Forgotten: Knowledge Flows, Labor Mobility, and Enduring Social Relationships", Journal of Economic Geography 6:5 (2006), 571-591.

Agrawal, Ajay, Devesh Kapur, John McHale, and Alexander Oettl, "Brain Drain or Brain Bank? The Impact of Skilled Emigration on Poor-Country Innovation", Journal of Urban Economics 69 (2011), 43-55.

Alcacer, Juan, and Wilbur Chung, "Location Strategies and Knowledge Spillovers", Management Science 53:5 (2007), 760-776.

Alcacer, Juan, and Minyuan Zhao, "Local R\&D Strategies and Multi-location Firms: The Role of Internal Linkages", Management Science (2011), forthcoming.

Almeida, Paul, and Bruce Kogut, "Localization of Knowledge and the Mobility of Engineers in Regional Networks", Management Science 45:7 (1999), 905-917.

Arora, Ashish, and Alfonso Gambardella, From Underdogs to Tigers? The Rise and Growth of the Software Industry in Brazil, China, India, Ireland, and Israel, (Oxford, UK: Oxford University Press, 2005).

Balakrishnan, Srinivasan, and Mitchell Koza, "Information Asymmetry, Adverse Selection and Joint-Ventures: Theory and Evidence", Journal of Economic Behavior EG Organization 20 (1993), 99-117.

Bhattacharya, Utpal, and Peter Groznik, "Melting Pot or Salad Bowl: Some Evidence from U.S. Investments Abroad", Journal of Financial Markets 11:3 (2008), 228-258.

Branstetter, Lee, "Is Foreign Direct Investment a Channel of Knowledge Spillovers? Evidence from Japan's FDI in the United States", Journal of International Economics 68 (2006), 325-344.

Buch, Claudia, Jörn Kleinert, and Farid Toubal, "Where Enterprises Lead, People Follow? Links Between Migration and German FDI", European Economic Review 50:8 (2006), 2017-2036.

Card, David, "Immigrant Inflows, Native Outflows, and the Local Labor Market Impacts of Higher Immigration", Journal of Labor Economics 19:1 (2001), 22-64. 
Choudhury, Prithwiraj, "Internal Labor Markets and Knowledge Creation in Multinationals", Working Paper (2010).

Clemens, Michael, "Skill Flow: A Fundamental Reconsideration of Skilled-Worker Migration and Development", United Nations Human Development Report (2009).

Dalton, D.H., M.G. Serapio, and P.G. Yoshida. Globalizing Industrial Research and Development (Washington, DC: U.S. Department of Commerce, Technology Administration, 1999).

Desai, Mihir, C. Fritz Foley, and James R. Hines Jr., "The Costs of Shared Ownership: Evidence from International Joint Ventures", Journal of Financial Economics 73:2 (2004), 323-374.

Docquier, Frédéric, and Elisabetta Lodigiani, "Skilled Migration and Business Networks", Open Economies Review 21:4 (2010), 565-588.

Docquier, Frédéric, and Hillel Rapoport, "The Economics of the Brain Drain", Journal of Economic Literature, forthcoming (2011).

Freeman, Richard, "People Flows in Globalization", Journal of Economic Perspectives 20:2 (2006), 145-170.

Gould, David, "Immigrant Links to the Home Country: Empirical Implications for U.S. Bilateral Trade Flows", Review of Economics and Statistics 76 (1994), 302-316.

Government of India, The High Level Committee on the Indian Diaspora (2001), http://indiandiaspora.nic.in/contents.htm.

Griliches, Zvi, "Patent Statistics as Economic Indicators: A Survey", Journal of Economic Literature 28:4 (1990), 1661-1707.

Hatzigeorgiou, Andreas, and Magnus Lodefalk, "Trade and Migration: Firm-Level Evidence", Working Paper (2011).

Hall, Bronwyn, Adam Jaffe, and Manuel Trajtenberg, "The NBER Patent Citation Data File: Lessons, Insights and Methodological Tools", NBER Working Paper 8498 (2001).

Head, Keith, and John Ries, "Immigration and Trade Creation: Econometric Evidence from Canada", Canadian Journal of Economics 31:1 (1998), 47-62.

Hernandez, Exequiel, "Immigrant Social Capital and Firm Strategic Heterogeneity: Effects on Foreign Entry and Firm Performance", Working Paper (2011).

Hovhannisyan, Nune, and Wolfgang Keller, "International Business Travel: An Engine of Innovation?", Working Paper (2010).

Huang, Yasheng, Li Jin, and Yi Qian, "Does Ethnicity Pay? Evidence from Overseas Chinese FDI in China", Review of Economics and Statistics, forthcoming (2011).

Hunt, Jennifer, and Marjolaine Gauthier-Loiselle, "How Much Does Immigration Boost Innovation?", American Economic Journal: Macroeconomics 2 (2010), 31-56.

Iriyama, Akie, Yong Li, and Ravi Madhavan, "Spiky Globalization of Venture Capital Investments: The Influence of Prior Human Networks", Strategic Entrepreneurship Journal 4 (2010), $128-145$.

Javorcik, Beata, Çağlar Özden, Mariana Spatareanu, and Cristina Neagu, "Migrant Networks and Foreign Direct Investment", Journal of Development Economics 94:2 (2011), 231-241.

Keller, Wolfgang, "International Technology Diffusion", Journal of Economic Literature 42:3 (2004), 752-782.

Kerr, William, "The Ethnic Composition of US Inventors", HBS Working Paper 08-006 (2007). 
Kerr, William, "Ethnic Scientific Communities and International Technology Diffusion", Review of Economics and Statistics 90:3 (2008), 518-537.

Kerr, William, "Heterogeneous Technology Diffusion and Ricardian Trade Patterns", HBS Working Paper (2009).

Kerr, William, "The Agglomeration of US Ethnic Inventors", in Edward Glaeser (ed.) Economics of Agglomeration (Chicago, IL: University of Chicago Press, 2010).

Kerr, William, and William Lincoln, "The Supply Side of Innovation: H-1B Visa Reforms and U.S. Ethnic Invention", Journal of Labor Economics 28:3 (2010), 473-508.

Kugler, Maurice, and Hillel Rapoport, "International Labor and Capital Flows: Complements or Substitutes?", Economics Letters 92:2 (2007), 155-162.

Kugler, Maurice, and Hillel Rapoport, "Migration, FDI and the Margins of Trade", Working Paper (2011).

MacGarvie, Megan, "The Determinants of International Knowledge Diffusion as Measured by Patent Citations", Economics Letters 87:1 (2005), 121-126.

MacGarvie, Megan, "Foreign Students and the Diffusion of Scientific and Technological Knowledge to and from American Universities", Working Paper (2006).

Mataloni, Raymond, "A Guide to BEA Statistics on U.S. Multinational Companies", Survey of Current Business 75 (1995).

Mataloni, Raymond, and Daniel Yorgason, "Operations of U.S. Multinational Companies", Survey of Current Business 82 (2002).

Nachum, Lilach, "But How Does Distance Affect FDI? And Why Does It Matter?" Working Paper (2011).

Nachum, Lilach, Srilata Zaheer, and Shulamith Gross, "Does it Matter Where Countries Are? Proximity to Knowledge, Markets and Resources, and MNE Location Choices", Management Science 54:7 (2008), 1252-1265.

Nanda, Ramana, and Tarun Khanna, "Diasporas and Domestic Entrepreneurs: Evidence from the Indian Software Industry", Journal of Economics and Management Strategy 19:4 (2010), 991-1012.

National Science Foundation, Science and Engineering Indicators (Arlington, VA: National Science Board, 2010).

Niosi, Jorge, "The Internationalization of Industrial R\&D: From Technology Transfer to the Learning Organization", Research Policy 28 (1999), 107-117.

Oettl, Alexander, and Ajay Agrawal, "International Labor Mobility and Knowledge Flow Externalities", Journal of International Business Studies 39:8 (2008), 1242-1260.

Papageorgiou, Chris, and Antonio Spilimbergo, "Learning Abroad and Technology Adoption", Working Paper (2008).

Puga, Diego, and Daniel Trefler, "Wake Up and Smell the Ginseng: The Rise of Incremental Innovation in Low-Wage Countries", Journal of Development Economics 91:1 (2010), 64-76.

Rangan, Subramanian, and Aldemir Drummond, "The Problem of Control and the Role of Home-Host Ties in Explaining Multinationals' Foreign Operations, Competitiveness, and Performance", Global Strategy Journal 1 (2011), 362-376.

Rangan, Subramanian, and Metin Sengul, "The Influence of Macro Structure on the Foreign Market Performance of Transnational Firms: The Value of IGO Connections, Export Dependence, and Immigration Links", Administrative Science Quarterly 54 (2009), 229-267. 
Rauch, James, "Networks Versus Markets in International Trade", Journal of International Economics 48:1 (1999), 7-35.

Rauch, James, "Business and Social Networks in International Trade", Journal of Economic Literature 39:4 (2001), 1177-1203.

Rauch, James, and Vitor Trindade, "Ethnic Chinese Networks in International Trade", Review of Economics and Statistics 84:1 (2002), 116-130.

Rosenkopf, Lori, and Paul Almeida, "Overcoming Local Search through Alliances and Mobility", Management Science 49:6 (2003), 751-766.

Saxenian, AnnaLee, "Silicon Valley's New Immigrant Entrepreneurs", (San Francisco, CA: Public Policy Institute of California, 1999).

Saxenian, AnnaLee, The New Argonauts (Cambridge, MA: Harvard University Press, 2006).

Saxenian, AnnaLee, "Transnational Communities and the Evolution of Global Production Networks: Taiwan, China and India", Industry and Innovation 9:3 (2002).

Saxenian, AnnaLee, with Yasuyuki Motoyama and Xiaohong Quan, Local and Global Networks of Immigrant Professionals in Silicon Valley (San Francisco, CA: Public Policy Institute of California, 2002).

Shatz, Howard, "The Location of U.S. Multinational Affiliates", Harvard Dissertation (2000).

Singh, Jasjit, "Multinational Firms and International Knowledge Diffusion: Evidence from Patent Citation Data", Best Paper Proceedings of the Academy of Management (2004).

Singh, Jasjit, "Collaborative Networks as Determinants of Knowledge Diffusion Patterns", Management Science 51:5 (2005), 756-770.

Singh, Jasjit, "Asymmetry of Knowledge Spillovers between MNCs and Host Country Firms", Journal of International Business Studies 38:5 (2007), 764-786.

Singh, Jasjit, "Distributed R\&D, Cross-Regional Knowledge Integration and Quality of Innovative Output", Research Policy 37:1 (2008), 77-96.

Thursby Jerry, and Marie Thursby, Here or There? A Survey on the Factors in Multinational RESD Location (Washington, DC: National Academies Press, 2006).

Veugelers, Reinhilde, and Bruno Cassiman, "Foreign Subsidiaries as a Channel of International Technology Diffusion: Some Direct Firm Level Evidence from Belgium", European Economic Review 48:2 (2004), 455-476.

von Zedtwitz, Maximilian, and Oliver Gassmann, "Market versus Technology Drive in R\&D Internationalization: Four Different Patterns of Managing Research and Development", Research Policy 31 (2002), 569-588.

Zhao, Minyaun, "Conducting R\&D in Countries with Weak Intellectual Property Rights Protection", Management Science 56:7 (2006), 1185-1199.

Zhao, Minyaun, and Mazhar Islam, "Cross-Regional Ties within Firms: Promoting Knowledge Flow or Discouraging Knowledge Spillover", Working Paper (2011). 


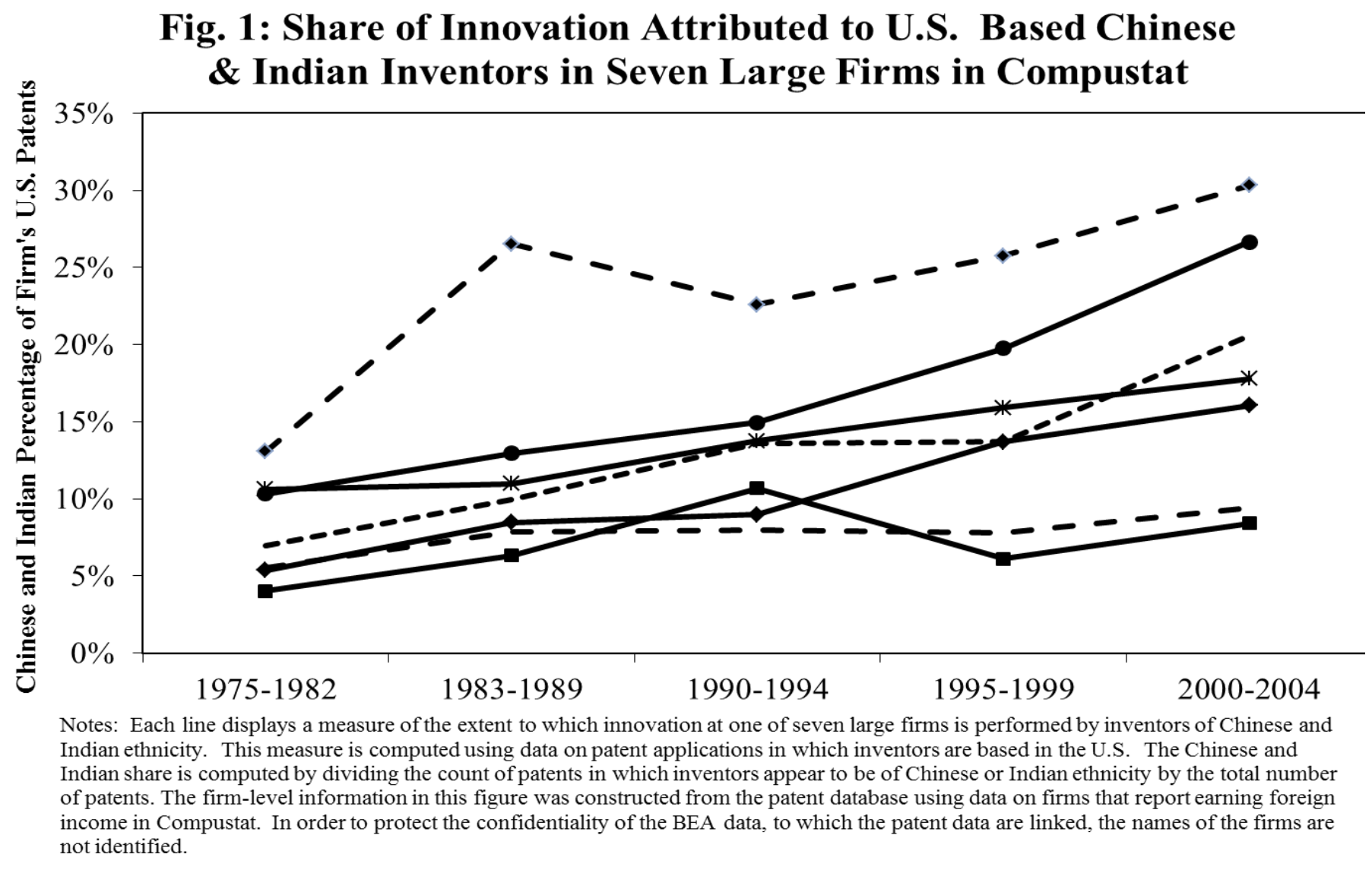

\section{Table 1}

Ethnic Shares of Patenting Activity

\begin{tabular}{lccccccccc}
\hline & \multicolumn{1}{c}{ Ethnicity of Inventors } \\
& Anglo- & Chinese & European & Hispanic & Indian & Japanese & Korean & Russian & $\begin{array}{c}\text { Viet- } \\
\text { namese }\end{array}$ \\
& Saxon & & & & & & & & \\
\hline $1975-1982$ & $81.3 \%$ & $2.8 \%$ & $8.3 \%$ & $2.8 \%$ & $2.5 \%$ & $0.6 \%$ & $0.5 \%$ & $1.2 \%$ & $0.1 \%$ \\
$1983-1989$ & $78.5 \%$ & $4.2 \%$ & $7.8 \%$ & $2.9 \%$ & $3.5 \%$ & $0.7 \%$ & $0.6 \%$ & $1.5 \%$ & $0.2 \%$ \\
$1990-1994$ & $76.4 \%$ & $5.4 \%$ & $7.3 \%$ & $3.4 \%$ & $4.2 \%$ & $0.6 \%$ & $0.6 \%$ & $1.6 \%$ & $0.5 \%$ \\
$1995-1999$ & $72.8 \%$ & $7.3 \%$ & $6.5 \%$ & $3.7 \%$ & $5.8 \%$ & $0.7 \%$ & $0.7 \%$ & $1.7 \%$ & $0.7 \%$ \\
$2000-2004$ & $68.0 \%$ & $9.5 \%$ & $6.2 \%$ & $4.0 \%$ & $7.3 \%$ & $1.0 \%$ & $1.1 \%$ & $2.2 \%$ & $0.8 \%$ \\
Chemicals & $74.1 \%$ & $6.6 \%$ & $8.1 \%$ & $3.5 \%$ & $4.5 \%$ & $0.7 \%$ & $0.8 \%$ & $1.4 \%$ & $0.3 \%$ \\
Computers & $70.7 \%$ & $7.7 \%$ & $6.3 \%$ & $3.5 \%$ & $7.3 \%$ & $0.9 \%$ & $0.7 \%$ & $2.1 \%$ & $0.8 \%$ \\
Pharmaceuticals & $74.9 \%$ & $6.0 \%$ & $7.5 \%$ & $4.2 \%$ & $4.1 \%$ & $0.7 \%$ & $0.7 \%$ & $1.4 \%$ & $0.3 \%$ \\
Electrical & $73.2 \%$ & $7.2 \%$ & $7.0 \%$ & $3.2 \%$ & $5.0 \%$ & $0.9 \%$ & $0.8 \%$ & $1.9 \%$ & $0.7 \%$ \\
Mechanical & $81.3 \%$ & $2.8 \%$ & $7.6 \%$ & $2.9 \%$ & $2.8 \%$ & $0.5 \%$ & $0.5 \%$ & $1.4 \%$ & $0.2 \%$ \\
Miscellaneous & $81.3 \%$ & $3.2 \%$ & $7.2 \%$ & $3.1 \%$ & $2.7 \%$ & $0.5 \%$ & $0.4 \%$ & $1.3 \%$ & $0.3 \%$ \\
\hline
\end{tabular}

Notes: This table presents the share of patents in which inventors are of particular ethnicities, reside in the U.S. at the time of patent application, and work for a publicly listed corporation. Inventor ethnicities are estimated through inventors' names using techniques described in the text. Patents are grouped by application years and major technology fields. 


\section{Table 2}

\section{Descriptive Statistics}

\begin{tabular}{|c|c|c|}
\hline & Mean & $\begin{array}{l}\text { Standard } \\
\text { Deviation }\end{array}$ \\
\hline Asset Share & 0.1899 & 0.2339 \\
\hline Sales Share & 0.1945 & 0.2251 \\
\hline Employment Share & 0.1959 & 0.2294 \\
\hline Employment Compensation Share & 0.1944 & 0.2363 \\
\hline Ethnic Share of U.S. Patents & 0.0403 & 0.0521 \\
\hline Predicted Ethnic Share of U.S. Patents & 0.0473 & 0.0681 \\
\hline Foreign R\&D Dummy & 0.3840 & 0.4864 \\
\hline $\log (1+$ Foreign $R \& D)$ & 2.8022 & 3.8189 \\
\hline Log (1 + Ethnic U.S. Patents) (Table 6) & 0.8960 & 1.0293 \\
\hline Log $(1+$ Predicted Ethnic U.S. Patents) (Table 6) & 0.9457 & 1.1156 \\
\hline Log (1 + Parent R\&D Expenditures $)$ & 10.7375 & 2.9150 \\
\hline $\log (1+$ Parent Sales $)$ & 14.6533 & 1.6093 \\
\hline Foreign Patenting Dummy & 0.0838 & 0.2772 \\
\hline $\log (1+$ Foreign Patents $)$ & 0.1338 & 0.5466 \\
\hline Log (1 + Ethnic U.S. Patents) (Table 7) & 0.4755 & 0.8342 \\
\hline Log (1 + Predicted Ethnic U.S. Patents) (Table 7) & 0.4916 & 0.8689 \\
\hline $\log (1+$ Firm R\&D) & 3.5147 & 1.7845 \\
\hline $\log (1+$ Firm Sales $)$ & 6.9092 & 1.8932 \\
\hline Whole Ownership Dummy & 0.7963 & 0.4028 \\
\hline Majority Ownership Dummy & 0.9205 & 0.2705 \\
\hline Log (1 + Ethnic U.S. Patents) (Table 8) & 1.5305 & 1.3122 \\
\hline Log (1 + Predicted Ethnic U.S. Patents) (Table 8) & 1.7048 & 1.5559 \\
\hline Ownership Restriction Dummy & 0.2455 & 0.4304 \\
\hline Ratio of Imports from Parent to Sales & 0.0893 & 0.2185 \\
\hline Ratio of Exports to Parent to Sales & 0.0283 & 0.1323 \\
\hline
\end{tabular}

Notes: Asset Share, Sales Share, Employment Share, and Employment Compensation Share capture the share of affiliate activity that occurs in countries associated with a particular ethnicity. Ethnic Share of U.S. Patents measures the firm's share of patents that cover inventions that occurred in the U.S. and were filed by inventors of a particular ethnicity. Predicted Ethnic Share of U.S. Patents is calculated by using the spatial distribution of a firm's initial inventor activity across cities and subsequent city-by-city growth of ethnic inventor populations. Foreign R\&D Dummy is a dummy equal to one for firms that incur R\&D expenditures within countries associated with a particular ethnicity. Log $(1+$ Foreign $R \& D)$ is the log of one plus the value of R\&D expenditures incurred within countries associated with a particular ethnicity. Log (1 + Ethnic U.S. Patents) is the log of one plus the number of patents that cover inventions that occurred in the U.S. and were filed by inventors of a particular ethnicity. Log ( 1 + Predicted Ethnic U.S. Patents) is calculated by using the spatial distribution of a firm's initial inventor activity across cities and subsequent city-by-city growth of ethnic inventor populations. The Table 6 measures of these variables are computed at the parent-ethnicity-year level where both ethnic patenting and affiliate activity exist, the Table 7 measures are computed at the parent-ethnicity-year level where ethnic patenting exists, and the Table 8 measures are computed at the affiliate level. Log ( $1+$ Parent R\&D Expenditures) and Log ( $1+$ Parent Sales) respectively measure the log of one plus the domestic R\&D expenditures and sales of a parent firm. Foreign Patenting Dummy is a dummy variable equal to one for firms that apply for at least one patent in which at least one inventor is based in a country associated with a particular ethnicity in the years preceding a benchmark survey year, and Log ( $1+$ Foreign Patents) is the log of one plus the number of these patents. Log ( 1 + Firm R\&D) and Log (1 + Firm Sales) are, respectively, the log of one plus firm R\&D expenditures and sales as measured in Compustat. Whole Ownership Dummy is a dummy equal to one for new affiliates that are wholly owned by their parent firms and zero for other new affiliates, and Majority Ownership Dummy is a dummy equal to one for new affiliates that are at least $50 \%$ owned by their parent firms and zero for other new affiliates. Ownership Restriction Dummy is based on Shatz (2000), and it is equal to one if both the acquisition and sectoral score are at least three in a particular country and year. Ratio of Imports from Parent to Sales is the ratio of affiliate imports from the U.S. parent to affiliate sales, and Ratio of Exports to Parent Sales is the ratio of affiliate exports to the U.S. parent to affiliate sales. Dollar amounts for BEA data are measured in thousands of dollars; dollar amounts for Compustat data are measured in millions of dollars. 
Table 3

Foreign Affiliate Activity

\begin{tabular}{|c|c|c|c|c|}
\hline \multirow[t]{3}{*}{ Dependent Variable: } & \multicolumn{4}{|c|}{ Affiliate Activity in Countries Associated with an Ethnicity } \\
\hline & Share of Assets & Share of Sales & $\begin{array}{c}\text { Share of } \\
\text { Employment }\end{array}$ & $\begin{array}{c}\text { Share of } \\
\text { Employment } \\
\text { Compensation }\end{array}$ \\
\hline & $(1)$ & $(2)$ & $(3)$ & $(4)$ \\
\hline Ethnic Share of U.S. Patents & $\begin{array}{c}0.1008 * * \\
(0.0413)\end{array}$ & $\begin{array}{c}0.0772 * * \\
(0.0324)\end{array}$ & $\begin{array}{l}0.0733 * \\
(0.0404)\end{array}$ & $\begin{array}{c}0.0794 * * \\
(0.0297)\end{array}$ \\
\hline Parent Firm x Ethnicity FE & Yes & Yes & Yes & Yes \\
\hline Ethnicity $\mathrm{x}$ Year FE & Yes & Yes & Yes & Yes \\
\hline Observations & 5,474 & 5,475 & 5,472 & 5,472 \\
\hline \multicolumn{5}{|c|}{$\begin{array}{l}\text { Notes: The dependent variables capture the share of affiliate activity that occurs in countries associated with a particular } \\
\text { ethnicity. The four columns respectively measure this share using affiliate assets, sales, employment levels, and } \\
\text { employment compensation, and the data used to compute these variables cover the years } 1982,1989,1994,1999 \text {, and } 2004 . \\
\text { Ethnic Share of U.S. Patents measures the share of a firm's patents that cover inventions that occurred in the U.S. and were } \\
\text { filed by inventors of a particular ethnicity. U.S. ethnic patenting shares are computed using data from the five years prior to } \\
\text { the shares of affiliate activity, except in the cases of } 1982 \text { and } 1989 \text { when seven-year time spans are used. All non-Anglo- } \\
\text { Saxon ethnicities are included. The specifications are OLS specifications that include fixed effects for each parent firm- } \\
\text { ethnicity and for each ethnicity-year. Heteroskedasticity-consistent standard errors that correct for clustering at the ethnicity- } \\
\text { year level appear in parentheses. } * * * * *, \text { and } * \text { denote significance at the } 1,5 \text {, and } 10 \text { percent levels, respectively. }\end{array}$} \\
\hline
\end{tabular}


Table 4

Foreign Affiliate Activity: New Foreign Innovators

\begin{tabular}{|c|c|c|c|c|}
\hline \multirow[t]{3}{*}{ Dependent Variable: } & \multicolumn{4}{|c|}{ Affiliate Activity in Countries Associated with an Ethnicity } \\
\hline & Share of Assets & Share of Sales & $\begin{array}{c}\text { Share of } \\
\text { Employment }\end{array}$ & $\begin{array}{c}\text { Share of } \\
\text { Employment } \\
\text { Compensation }\end{array}$ \\
\hline & $(1)$ & $(2)$ & (3) & (4) \\
\hline & \multicolumn{4}{|c|}{ A. New Foreign Innovators } \\
\hline Ethnic Share of U.S. Patents & $\begin{array}{c}0.2155 * * \\
(0.0991)\end{array}$ & $\begin{array}{c}0.2547 * * * \\
(0.0852)\end{array}$ & $\begin{array}{l}0.1541 * \\
(0.0886)\end{array}$ & $\begin{array}{c}0.2491 * * * \\
(0.0653)\end{array}$ \\
\hline Parent Firm x Ethnicity FE & Yes & Yes & Yes & Yes \\
\hline Ethnicity x Year FE & Yes & Yes & Yes & Yes \\
\hline \multirow[t]{2}{*}{ Observations } & 2,200 & 2,201 & 2,200 & 2,200 \\
\hline & \multicolumn{4}{|c|}{ B. Other Observations } \\
\hline Ethnic Share of U.S. Patents & $\begin{array}{c}0.0551 \\
(0.0550)\end{array}$ & $\begin{array}{c}0.0084 \\
(0.0458)\end{array}$ & $\begin{array}{c}0.0387 \\
(0.0560)\end{array}$ & $\begin{array}{l}-0.0018 \\
(0.0481)\end{array}$ \\
\hline Parent Firm x Ethnicity FE & Yes & Yes & Yes & Yes \\
\hline Ethnicity x Year FE & Yes & Yes & Yes & Yes \\
\hline Observations & 3,274 & 3,274 & 3,272 & 3,272 \\
\hline
\end{tabular}

Notes: This table presents specifications like those in Table 3 for two subsamples. The New Foreign Innovators sample isolates firm-ethnicities for which the firms had: 1) previously applied for patents for innovations of U.S. based inventors and 2) subsequently applied for patents for innovations involving inventors located in countries of a particular ethnicity. The Other Observations sample includes other observations. ***, **, and * denote significance at the 1,5 , and 10 percent levels, respectively. 
Table 5

\section{Foreign Affiliate Activity: Predicted Share Estimates}

\begin{tabular}{|c|c|c|c|c|c|}
\hline \multirow[t]{3}{*}{ Dependent Variable: } & \multirow[b]{2}{*}{$\begin{array}{c}\text { Ethnic Share of } \\
\text { U.S. Patents }\end{array}$} & \multicolumn{4}{|c|}{ Affiliate Activity in Countries Associated with an Ethnicity } \\
\hline & & Share of Assets & Share of Sales & $\begin{array}{c}\text { Share of } \\
\text { Employment }\end{array}$ & $\begin{array}{c}\text { Share of } \\
\text { Employment } \\
\text { Compensation }\end{array}$ \\
\hline & (1) & (2) & (3) & (4) & $(5)$ \\
\hline Predicted Ethnic Share of U.S. & $0.1926 * *$ & 0.0403 & $0.1540 * *$ & $0.1492 * *$ & 0.0713 \\
\hline Patents & $(0.0717)$ & $(0.0628)$ & $(0.0607)$ & $(0.0647)$ & $(0.0577)$ \\
\hline Parent Firm x Ethnicity FE & Yes & Yes & Yes & Yes & Yes \\
\hline Ethnicity x Year FE & Yes & Yes & Yes & Yes & Yes \\
\hline Observations & 5,475 & 5,474 & 5,475 & 5,472 & 5,472 \\
\hline
\end{tabular}

Notes: The first column presents the relationship between the predicted and actual values of the ethnic share of U.S. patents. The dependent variables in the remaining columns capture the share of affiliate activity that occurs in countries associated with a particular ethnicity. Columns $2-5$ respectively measure this share using affiliate assets, sales, employment levels, and employment compensation, and the data used to compute these variables cover the years 1982, 1989, 1994, 1999, and 2004. Predicted Ethnic Share of U.S. Patents measures the expected share of patents that cover inventions that occurred in the U.S. and were filed by inventors of a particular ethnicity. These shares are calculated by combining the spatial distribution of a firm's initial inventor activity across cities with subsequent city-by-city growth of ethnic inventor populations. Own-firm inventors are removed from the city growth through a procedure discussed in the text. All non-Anglo-Saxon ethnicities are included.

Heteroskedasticity-consistent standard errors that correct for clustering at the ethnicity-year level appear in parentheses. ***,**, and * denote significance at the 1,5 , and 10 percent levels, respectively. 
Table 6

Foreign Affiliate R\&D

\begin{tabular}{|c|c|c|c|c|c|c|c|c|}
\hline \multirow[t]{2}{*}{ Dependent Variable: } & \multicolumn{4}{|c|}{ Foreign R\&D Dummy } & \multicolumn{4}{|c|}{$\log (1+$ Foreign $R \& D)$} \\
\hline & (1) & (2) & (3) & (4) & (5) & (6) & (7) & (8) \\
\hline Log (1 + Ethnic U.S. Patents) & $\begin{array}{c}0.0635 * * * \\
(0.0152)\end{array}$ & $\begin{array}{c}0.0396 * * \\
(0.0166)\end{array}$ & & & $\begin{array}{c}0.5571 * * * \\
(0.1262)\end{array}$ & $\begin{array}{c}0.3081 * * \\
(0.1461)\end{array}$ & & \\
\hline Log (1 + Predicted Ethnic U.S. Patents) & & & $\begin{array}{c}0.0242 \\
(0.0148)\end{array}$ & $\begin{array}{c}0.0199 \\
(0.0169)\end{array}$ & & & $\begin{array}{c}0.2900 * * \\
(0.1210)\end{array}$ & $\begin{array}{c}0.2744 * * \\
(0.1253)\end{array}$ \\
\hline Log (1 + Parent R\&D Expenditures) & & $\begin{array}{c}0.0077 * * \\
(0.0032)\end{array}$ & & $\begin{array}{c}0.0082 * * \\
(0.0032)\end{array}$ & & $\begin{array}{c}0.0856^{* * * *} \\
(0.0222)\end{array}$ & & $\begin{array}{c}0.0891 * * * \\
(0.0225)\end{array}$ \\
\hline $\log (1+$ Parent Sales $)$ & & $\begin{array}{c}0.0565 * * * \\
(0.0138)\end{array}$ & & $\begin{array}{c}0.0693 * * * \\
(0.0149)\end{array}$ & & $\begin{array}{c}0.5848 * * * \\
(0.1125)\end{array}$ & & $\begin{array}{c}0.6873 * * * \\
(0.1074)\end{array}$ \\
\hline Parent Firm x Ethnicity FE & Yes & Yes & Yes & Yes & Yes & Yes & Yes & Yes \\
\hline Ethnicity x Year FE & Yes & Yes & Yes & Yes & Yes & Yes & Yes & Yes \\
\hline Observations & 5,476 & 5,345 & 5,476 & 5,345 & 5,476 & 5,345 & 5,476 & 5,345 \\
\hline
\end{tabular}

Notes: The dependent variable in columns 1-4 is a dummy equal to one for firms that incur R\&D expenditures within countries associated with a particular ethnicity, and it is measured in 1982, 1989, 1994, 1999, and 2004. In columns 5-8 the dependent variable is the log of one plus the value of R\&D expenditures incurred by a firm within countries associated with a particular ethnicity. Log (1+ Ethnic U.S. Patents) is the log of one plus the parent firm's number of patents that cover inventions that occurred in the U.S. and were filed by inventors of a particular ethnicity. It is computed using data from the five years prior to the R\&D measures, except in the cases of 1982 and 1989 when seven-year time spans are used. $\log (1+$ Predicted Ethnic U.S. Patents $)$ is calculated by combining the spatial distribution of a firm's initial inventor activity across cities with subsequent city-by-city growth of ethnic inventor populations. Log (1 + Parent R\&D Expenditures) and Log (1 + Parent Sales) respectively measure the log of one plus the domestic R\&D expenditures and sales of a parent firm. All non-Anglo-Saxon ethnicities are included. The specifications are OLS specifications that include fixed effects for each parent firmethnicity and for each ethnicity-year. Heteroskedasticity-consistent standard errors that correct for clustering at the ethnicity-year level appear in parentheses. ***, **, and * denote significance at the 1,5 , and 10 percent levels, respectively. 
Table 7

Patenting Foreign Inventions

\begin{tabular}{|c|c|c|c|c|c|c|c|c|}
\hline \multirow[t]{2}{*}{ Dependent Variable: } & \multicolumn{4}{|c|}{ Foreign Patenting Dummy } & \multicolumn{4}{|c|}{ Log $(1+$ Foreign Patents $)$} \\
\hline & $(1)$ & $(2)$ & $(3)$ & (4) & $(5)$ & $(6)$ & $(7)$ & $(8)$ \\
\hline Log (1 + Ethnic U.S. Patents) & $\begin{array}{c}0.0790 * * * \\
(0.0085)\end{array}$ & $\begin{array}{c}0.0725^{* * *} * \\
(0.0088)\end{array}$ & & & $\begin{array}{c}0.2085^{* * * *} \\
(0.0248)\end{array}$ & $\begin{array}{c}0.2167 * * * \\
(0.0244)\end{array}$ & & \\
\hline Log (1 + Predicted Ethnic U.S. Patents) & & & $\begin{array}{c}0.0354 * * * \\
(0.0092)\end{array}$ & $\begin{array}{c}0.0341 * * * \\
(0.0086)\end{array}$ & & & $\begin{array}{c}0.1440 * * * \\
(0.0236)\end{array}$ & $\begin{array}{c}0.1469 * * * \\
(0.0236)\end{array}$ \\
\hline $\log (1+$ Firm R\&D) & & $\begin{array}{c}0.0083 \\
(0.0057)\end{array}$ & & $\begin{array}{c}0.0288 * * * \\
(0.0051)\end{array}$ & & $\begin{array}{c}0.0033 \\
(0.0097)\end{array}$ & & $\begin{array}{c}0.0628 * * * \\
(0.0132)\end{array}$ \\
\hline Log (1 + Firm Sales $)$ & & $\begin{array}{l}-0.0007 \\
(0.0056)\end{array}$ & & $\begin{array}{c}0.0020 \\
(0.0055)\end{array}$ & & $\begin{array}{l}-0.0181 \\
(0.0094)\end{array}$ & & $\begin{array}{l}-0.0078 \\
(0.0082)\end{array}$ \\
\hline Parent Firm x Ethnicity FE & Yes & Yes & Yes & Yes & Yes & Yes & Yes & Yes \\
\hline Ethnicity x Year FE & Yes & Yes & Yes & Yes & Yes & Yes & Yes & Yes \\
\hline Observations & 11,200 & 10,056 & 11,200 & 10,056 & 11,200 & 10,056 & 11,200 & 10,056 \\
\hline
\end{tabular}

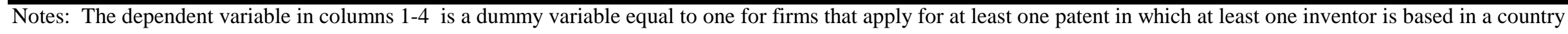

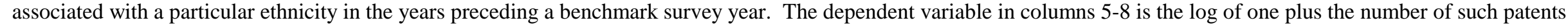

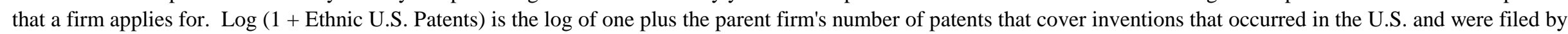

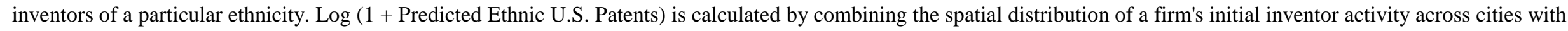

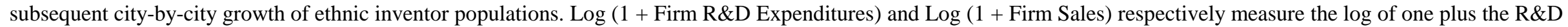

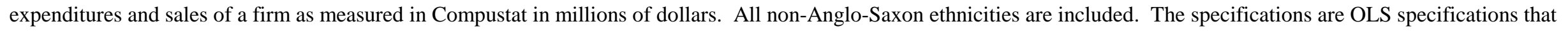

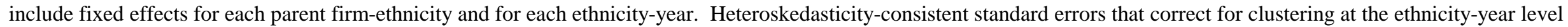
appear in parentheses. ***,**, and * denote significance at the 1, 5, and 10 percent levels, respectively. 
Table 8

Foreign Affiliate Ownership Structure

\begin{tabular}{|c|c|c|c|c|c|c|c|c|}
\hline \multirow[t]{2}{*}{ Dependent Variable: } & \multicolumn{4}{|c|}{ Whole Ownership Dummy } & \multicolumn{4}{|c|}{ Majority Ownership Dummy } \\
\hline & $(1)$ & $(2)$ & (3) & (4) & $(5)$ & $(6)$ & (7) & (8) \\
\hline Log (1 + Ethnic U.S. Patents) & $\begin{array}{c}0.0833 * * * \\
(0.0112)\end{array}$ & $\begin{array}{c}0.0708 * * * \\
(0.0137)\end{array}$ & & & $\begin{array}{c}0.0499 * * * \\
(0.0151)\end{array}$ & $\begin{array}{c}0.0543 * * * \\
(0.0191)\end{array}$ & & \\
\hline Log (1 + Predicted Ethnic U.S. Patents $)$ & & & $\begin{array}{c}0.0673 * * * \\
(0.0112)\end{array}$ & $\begin{array}{c}0.0727 * * * \\
(0.0122)\end{array}$ & & & $\begin{array}{c}0.0493 * * * \\
(0.0127)\end{array}$ & $\begin{array}{c}0.0649 * * * \\
(0.0164)\end{array}$ \\
\hline Ownership Restriction Dummy & & $\begin{array}{c}-0.1479 * * * \\
(0.0239)\end{array}$ & & $\begin{array}{c}-0.1541 * * * \\
(0.0229)\end{array}$ & & $\begin{array}{c}-0.0523 * * * \\
(0.0190)\end{array}$ & & $\begin{array}{c}-0.0544 * * * \\
(0.0182)\end{array}$ \\
\hline Ratio of Imports from Parent to Sales & & $\begin{array}{c}0.1274 * * * \\
(0.0349)\end{array}$ & & $\begin{array}{c}0.1295^{* * *} \\
(0.0350)\end{array}$ & & $\begin{array}{c}0.0714 * * * \\
(0.0253)\end{array}$ & & $\begin{array}{c}0.0750 * * * \\
(0.0253)\end{array}$ \\
\hline Ratio of Exports to Parent to Sales & & $\begin{array}{c}0.1135 * * \\
(0.0463)\end{array}$ & & $\begin{array}{c}0.1139 * * \\
(0.0469)\end{array}$ & & $\begin{array}{c}0.0595 * * \\
(0.0298)\end{array}$ & & $\begin{array}{c}0.0606 * * \\
(0.0300)\end{array}$ \\
\hline Parent Firm x Year FE & Yes & Yes & Yes & Yes & Yes & Yes & Yes & Yes \\
\hline Observations & 6,971 & 4,244 & 6,971 & 4,244 & 6,971 & 4,244 & 6,971 & 4,244 \\
\hline
\end{tabular}

Notes: The dependent variable in columns 1-4 is a dummy equal to one for new affiliates that are wholly owned by their parent firms and zero for other new affiliates, and the dependent variable in columns 5-8 is a dummy equal to one for new affiliates that are at least 50\% owned by their parent firms and zero for other new affiliates. New affiliates are identified in the years 1989, 1994, 1999, and 2004 as affiliates that were not present in the previous benchmark survey. Log (1+ Ethnic U.S. Patents) is the log of one plus the parent firm's number of patents that cover inventions that occurred in the U.S. and were filed by inventors of a particular ethnicity. It is computed using data from the five years prior to the ownership measures, except in the case of 1989 when a seven-year time span is used. Log ( $1+$ Predicted Ethnic U.S. Patents) is calculated by combining the spatial distribution of a firm's initial inventor activity across cities with subsequent city-by-city growth of ethnic inventor populations. The Ownership Restriction Dummy is based on Shatz (2000), and it is equal to one if both the acquisition and sectoral score are at least three in a particular country and year. Ratio of Imports from Parent to Sales is the ratio of affiliate imports from the U.S. parent to affiliate sales, and Ratio of Exports to Parent Sales is the ratio of affiliate exports to the U.S. parent to affiliate sales. All nonAnglo-Saxon ethnicities are included. The specifications are OLS specifications that include fixed effects for each parent firm-year. Heteroskedasticity-consistent standard errors that correct for clustering at the parent firm-year level appear in parentheses. ***,**, and $*$ denote significance at the 1,5 , and 10 percent levels, respectively. 